DOI: https://doi.org/10.32838/2523-4803/70-6-13

УДК 338.439.6(477)

Харабовський Ю.І.

аспірант кафедри економіки та економічної безпеки, Львівський державний університет внутрішніх справ

\title{
Kharabovskyi Yurii
}

Lviv State University of Internal Affairs

\section{ТЕОРЕТИЧНІ ОСНОВИ ЗАБЕЗПЕЧЕННЯ ПРОДОВОЛЬЧОЇ БЕЗПЕКИ}

\begin{abstract}
Проблема забезпечення продовольчої безпеки була і залишається актуальною для людства, адже безпосередньо пов'язана із необхідністю систематичного задоволення першочергової фізіологічної потреби в їжі. Зростання кількості населення планети, попри суттєвий поступ у більш ефективному використанні природних ресурсів, актуалізуе важливість наукового пошуку шляхів досягнення фізичної та економічної достатності продуктів харчування. Останні десятиліття ознаменувалися певною зміною спектру пріоритетних завдань, коли поруч із кількістю їжі важливими стали ї̈ якісні параметри, тобто вміст необхідних для підтримання життєздатності мінералів, відсутність шкідливих складників та систематичність надходження продуктів незалежно від урожайності та інтенсивності внутрішньо- та зовнішньоекономічних процесів у краӥні.

Ключові слова: продовольча безпека, безпека харчування, продукти харчування, продовольча доступність, продовольча достатність.
\end{abstract}

Постановка проблеми. Першочергова проблема кожної людини, яка потребує щоденного вирішення, пов’язана з необхідністю отримання певного обсягу продуктів харчування. Систематичне вирішення цієї проблеми суттєво впливає на життєздатність кожної особи. Можна стверджувати, що продовольча проблема супроводжує людство на усіх етапах його розвитку i, попри суттєвий поступ у науково-технічній сфері та все більш активне використання природних ресурсів, не стає менш актуальною. Більше того, у другій половині XX ст. внаслідок ускладнення доступу населення більшості країн до продуктів харчування ця проблема набула глобального характеру, що вимагає застосування консолідованого підходу на міжнародному рівні.

Важливість вирішення продовольчої проблеми можна проілюструвати висловлюванням Е. Батца, який у 1975 р. констатував той факт, що «в сучасному світі є лише два справжніх види влади: влада нафти та влада продовольства» [4, с. 221]. Завдяки більш активному використанню відновлювальних джерел енергії вплив сили влади нафти поступово зменшується, а продовольства - зростає. Зумовлюється це насамперед подальшим зростанням народонаселення нашої планети та відповідно збільшенням попиту на якісні, екологічно чисті та збалансовані мінералами продукти, що $є$ неможливим внаслідок зменшення площ земель сільськогосподарського призначення через посилення процесів урбанізації. Відповідно до аналітичних даних звіту The Economist Intelligence Unit, який був підготов-лений за підтримки Corteva Agriscience, у 2019 році понад 820 млн людей голодували, а більше 30\% країн повідомили про недостатньо збалансований раціон харчування громадян, зокрема в частині постійного отримання доступу до необхідних мінералів [3]. Усе зазначене доводить важливість приділення уваги проблемі забезпечення продовольчої безпеки, яка є актуальною і для України.

Аналіз останніх досліджень і публікацій. Методологічні аспекти забезпечення продовольчої безпеки розглядаються в публікаціях таких науковців, як О. Білорус, І. Бінько, Ю. Валєтова, В. Геєць, К. Голівкова, Л. Дейнеко, В. Срмоленко, С. Кваша, В. Ковальов, С. Лушпаєв, Л. Міляр, Я. Пушак, Р. Трінько, В. Шлемко та інші. В їхніх дослідженнях сформований понятійнокатегоріальний апарат та обгрунтовано важливість наукового пошуку шляхів вирішення найбільш важливих проблем у сфері продовольчої безпеки не лише загалом, але і з конкретизацією на взаємопов'язаних рівнях: глобальному, національному, регіональному, домогосподарств та індивідуума.

Формування цілей статті. Метою статті є дослідження генезису формування поняття «продовольча безпека», визначення основних наукових підходів до його трактування та окреслення аспектів забезпечення в сучасних умовах.

Виклад основного матеріалу. Технологічний поступ та посилення глобалізаційних процесів повинні були сприяти вирішенню проблем задоволення первинних потреб кожної особи в їжі. Попри зазначене, фактично проблема забезпечення продовольчої безпеки стала ще гострішою, оскільки поруч із доступністю їжі постало питання щодо її безпечності, яке пов'язане із безконтрольним застосуванням шкідливих хімічних речовин під час виробництва продуктів харчування, 
які за умови тривалого споживання можуть спричинити зниження імунозахисних функцій організму, його інтоксикацію, ожиріння та пришвидшити темпи старіння. Наукова спільнота стала активним учасником дослідження процесів забезпечення продовольчої безпеки, що знайшло відображення у публікаціях учених різних країн, адже ця проблема, спричинивши посилення міграційних процесів, стала актуальною для всіх країн.

Історичні корені формування поняття «продовольча безпека» безпосередньо пов'язані із сприйняттям нашими предками голоду як фізіологічного явища, що пов’язано із відсутністю необхідних продуктів для підтримання життєздатності організму на належному рівні. Історики саме з голодом пов'язують найбільші соціальні катаклізми, які були притаманні для кожного етапу розвитку людства. Хорошою ілюстрацією зазначеного можна вважати висловлювання французького історика I. Броделя, який стверджував, що «протягом багатьох віків голод повертався 3 такою настирливістю, що став елементом біологічного режиму людей, однією зі структур їхнього буденного життя» [2]. Як приклад, доцільно згадати той факт, що у XVIII ст. голод на території Бенгалії спричинив смерть більше 10 млн осіб, тобто кожного третього громадянина. У ХІХ ст. Свропа періодично зазнавала суттєвих людських втрат через неврожай картоплі, а в Індії кількість жертв сягнула 15 млн осіб. Суттєвий вплив голоду на соціальні процеси в більшості країн залишився і в XX ст., прикладом чого можуть бути катастрофічні втрати людських ресурсів на території України в 30-х роках.

Друга світова війна суттєво вплинула на продовольче забезпечення громадян більшості європейських країн, що стало поштовхом до консолідації зусиль їніх урядів щодо удосконалення механізмів систематичного і безперервного надходження продуктів до споживачів, зокрема і шляхом більш інтенсивного розвитку сільського господарства та активізації міжнародної торгівлі. Провідну роль у розробленні узгодженої політики щодо недопущення голоду почала відігравати Продовольча та сільськогосподарська організація Об’єднаних Націй (ФАО), яка взяла за основу гасло «допомагаємо побудувати світ без голоду» [9].

У 50-60-х роках більшість країн орієнтувалися на збільшення виробництва сільськогосподарської продукції, лідерами серед яких стали пшениця і рис, для забезпечення власної продовольчої незалежності. Тобто продовольча безпека пов'язувалася із можливістю виробництва необхідного обсягу харчової продукції та мінімізацією залежності від іноземних товаровиробників. Ситуація суттєво змінилася у 70-х роках, коли внаслідок різких змін в обсягах вирощування зернових культур ціни на світовому ринку зросли, позбавивши значну частину населення можливості придбати необхідні продукти харчування. Зазначені обставини стали поштовхом до організації Світової продовольчої конференції у Римі, яка пройшла за участі представників 134 країн світу, а їі результатом стало формулю- вання одного із перших офіційних визначень поняття «продовольча безпека» як «наявність у будь-який час необхідних світових продовольчих запасів основних продуктів харчування, достатніх для підтримки стійкого та розширеного споживання, і для компенсації коливань обсягів виробництва та цін» [9].

Завдяки науковій роботі лауреата Нобелівської премії А. Сена, в якій автор акцентував увагу на важливості розгляду проблем забезпечення продовольчої безпеки не лише на національному рівні, але й із концентрацією уваги на рівні окремих домогосподарств та осіб, відбулося уточнення трактування цього поняття. Науковець наполягав на важливості врахування інтересів потенційно вразливих категорій населення, які не здатні самостійно забезпечити необхідний рівень продовольчої безпеки. У 1983 р. ФАО запропонувало тлумачити продовольчу безпеку як «гарантію того, що всі люди у будь-який час будуть мати фізичну та економічну доступність до основних продуктів харчування, в яких у них є потреба» [9]. У цьому визначенні акцентовано увагу на таких принципово важливих моментах, як: забезпечення «фізичної доступності продовольства», тобто його достатня кількість для усіх громадян; досягнення «економічної доступності» через формування можливостей кожної особи придбати необхідний набір продуктів; формування каналів стабільного постачання домогосподарств незалежно від зміни ситуації в країні та на світових ринках.

Наступний етап еволюції поняття «продовольча безпека» був пов'язаний із застосуванням у середині 90-х років терміну «безпека харчування». У доповіді Міжнародного дослідницького інституту продовольчої політики було запропоновано безпеку харчування розуміти як «належний нутрітивний статус із погляду засвоєних білків, калорій, вітамінів та мінералів усіх членів домогосподарства» [12]. Можна стверджувати, що в наукових колах була відсутня узгоджена позиція щодо співвідношення термінів «продовольча безпека» i «безпека харчування», адже, попри згоду про наявність сильного зв'язку, відбувалися дискусії щодо їх співвідношення, тобто який із них $є$ більш загальним i містить інший як один зі складників.

Нове тисячоліття ознаменувалося активізацією пошуку умов досягнення продовольчої безпеки на усіх рівнях, тобто як міжнародному й національному, так i окремих домогосподарств. Свідченням цього є позиція ЮНІСЕФ, згідно з якою «продовольча безпека та безпека харчування досягаються тоді, коли відповідна їжа (за кількістю, якістю, безпекою, соціально-економічною належністю) доступна для всіх людей у будь-який час і відповідно споживається та засвоюється ними для ведення здорового та активного способу життя» [10]. Тобто продовольча безпека розглядається із врахуванням кількісних та якісних параметрів продуктів харчування та систематичністю їх споживання усіма особами.

Світова організація торгівлі у визначенні продовольчої безпеки акцентує увагу на необхідності 
дотримання трьох базових принципів: «продовольчої достатності», «продовольчого доступу» та «продовольчого використання». При цьому йдеться не лише про доступність, достатність та якість продуктів харчування, але й про водопостачання й санітарію.

Серед науковців відсутня узгоджена позиція щодо суті поняття «продовольча безпека». Здійснене узагальнення дало змогу виділити та дати коротку характеристику основним підходам до трактування цього поняття, орієнтуючись насамперед на виявленні найсуттєвіші відмінності у поглядах науковців. Так, в основі першого підходу лежить орієнтація на вирішення проблем продовольчої безпеки у глобальному вимірі, що повинно забезпечити виживання не громадян окремої країни чи регіону, а людства загалом. Здебільшого прихильниками такого підходу є представники наукових кіл економічно розвинутих держав. Для прикладу, Л. Мастерс дотримується такої позиції, що «забезпечення глобальної продовольчої безпеки є комплексною проблемою, що містить у собі виробництво продовольства у світовому масштабі, потреби й попит на продовольство як по-хідну від кількості й рівня життя населення у світі, експорт/імпорт продовольства як найважливіший фактор забезпечення необхідного рівня споживання, а також міжнародне регулювання й довгострокову стратегію» [11, с. 79]. Зважаючи на дані, які були подані вище, щодо кількості населення планети, яке перебуває на межі виживання через недостатню кількість їжі або iii низьку якість за структурою необхідних мінералів, такий підхід є доречним, зокрема в процесі посилення міжнародної взаємодії.

В основі другого підходу лежить доступність для громадян необхідних їм для підтримання своєї життєздатності продуктів харчування. Прихильником такого підходу є Р. Тринько, який визначає продовольчу безпеку як «спроможність держави за будь-яких обставин гарантувати і забезпечувати потреби населення в екологічно чистому продовольстві на рівні науково обгрунтованого споживання за платоспроможності за умов, коли третина доходу витрачається на харчування» [8, с. 252]. Акцент на фізичну та економічну доступність є особливо важливим у контексті забезпечення продовольчої безпеки нашої країни, адже за розвинутого виробництва сільськогосподарської продукції частина громадян обмежена в можливості її придбання через критично низький рівень доходів.

Третій підхід нами сформований на основі наукових праць, де доводиться важливість самозабезпечення держави. Так, А. Бабенко наполягає на пріоритетності забезпечення продовольчої безпеки «внутрішніми, національними силами для забезпечення громадян продуктами харчування на медично обгрунтованому рівні» $[1$, с. 12]. Така позиція важлива, адже формує основу для підтримання національного товаровиробника, забезпечення необхідного рівня платоспроможності населення та зменшення залежності від імпорту, через який інші країни можуть загрожувати реалізації національним інтересам.
Четвертий підхід різниться від попереднього тим, що науковці допускають для забезпечення продовольчої безпеки як стимулювання внутрішнього виробництва, так і сприяння збільшенню імпорту продуктів харчування, визначаючи пріоритетним споживання. Г. Прунцева обгрунтовує необхідність розуміти під продовольчою безпекою «сукупність державних інструментів регулювання стану продовольчого ринку, за якого досягається фізична та економічна доступність населення до продовольства у кількості, необхідній для активного здорового життя» [6, с. 35].

Узагальнюючи, доцільно підкреслити, що кожен iз підходів відображає певний важливий аспект, який заслуговує на увагу, оскільки проблема забезпечення продовольчої безпеки є комплексною і вимагає пошуку оптимальних у певних умовах шляхів вирішення, які можуть різнитися залежно від політичних, економічних та соціальних процесів у кожній окремій країні.

Якщо проблема продовольчої безпеки на міжнародному та національному рівні перебуває постійно в полі зору науковців, то дослідження стосовно інших ієрархічних рівнів здійснюються менш активно, що внаслідок сильного міжрівневого зв'язку скоріше негативно впливає на можливість вирішення ключових завдань. Для прикладу, міжрівневий зв'язок чітко простежується у визначенні поняття «продовольчої безпеки регіону», під яким Я. Пушак та І. Пушак пропонують розуміти «стан економіки регіону, забезпечений ресурсним, фінансовим, науково-дослідним, технологічним, виробничим і кадровим потенціалом галузей агропромислового комплексу, харчової промисловості і торгівлі, які пов'язані із продовольчим забезпеченням населення, що гарантує незалежність від внутрішніх і зовнішніх загроз, доступність для всього населення регіону продуктів харчування в обсязі, якості й асортименті, достатніх для підтримки здоров’я і працездатності в надзвичайних ситуаціях» [7, с. 42]. Вважаємо за доцільне погодитися із здійсненою авторами конкретизацією умови забезпечення продовольчої безпеки, яка визначається наявним потенціалом регіону, що і формує основу задоволення потреби його мешканців у необхідних продуктах.

Доцільно зазначити, що в проекті Закону України «Про продовольчу безпеку України» це поняття визначено як «соціально-економічний та екологічний стан у державі, за якого всі їі громадяни стабільно та гарантовано забезпечені продовольством у необхідній кількості, асортименті та відповідної якості» [5]. Потрібно визнати і той факт, що цей закон був прийнятий Верховною Радою України за основу 14.06.2011 р., але в подальшому відправлений на доопрацювання. Поруч із цим проблема продовольчої безпеки є критично важливою сьогодні внаслідок військових дій на території нашої країни, жертвами яких стали понад 4,4 мільйона цивільних осіб, які зазначають суттєвих труднощів не лише щодо місця постійного безпечного проживання, але й отримання доступу до необхідної кількості якісних харчових продуктів. 
Висновки. Проблема забезпечення продовольчої безпеки сьогодні стоїть доволі гостро перед нашою країною, попри значний потенціал сільськогосподарського сектору. Військові дії, низька купівельна спроможність населення, технологічне відставання сільськогосподарських підприємства, нераціональне використання земельних ресурсів, зростання імпортних продуктів харчування та інші фактори вимагають активізації та наукового обгрунтування шляхів досягнення достатньої кількості продуктів харчування, забезпечення доступності продовольства для усіх верств населення; механізмів контролю за складом та якістю продуктів, а також стабільністю їх поставок.

Важливо підкреслити, що в поточних умовах продовольчу безпеку доцільно трактувати як гарантію незалежності, а іії забезпечення залежить як від темпів розвитку сільського господарства, так і від стабільності національної економіки.

Складність та важливість досліджуваної проблеми вимагає в подальшому зосередження уваги на розгляді стратегічних пріоритетів та механізмів реалізації державної політики у сфері продовольчої безпеки.

\section{Список літератури:}

1. Бабенко А.А. Забезпечення продовольчої безпеки України в умовах реформуванні і регулювання аграрного сектору економіки : автореф. дис. ... канд. екон. наук : 08.00.04. Луганськ, 2005. 24 с.

2. Бродель Фернан. Материальная цивилизация, экономика и капитализм, XV-XVIII вв. Москва : Весь мир, 2006. URL : http://demoscope.ru/weekly/knigi/brodel/brodel.pdf (дата звернення: 08.11.2020).

3. Глобальний індекс продовольчої безпеки 2019. The Economist In-telligence Unit. URL: https://infoindustria.com.ua/ opublikovano-globalnij-indeks-prodovolcho\%D1\%97-bezpeki-2019/ (дата звернення: 08.11.2020)

4. Кашенко О.Л. Екологічна складова національної продовольчої безпеки. Нова економічна парадигма формування стратегії національної продовольчої безпеки України у XXI столітті. Київ : IAE, 2001. 356 с.

5. Про продовольчу безпеку України : проект Закону України від 28.04.2011 p. № 8370-1. URL: http://search.ligazakon.ua/ 1_doc2.nsf/link1/JF6GI01I.html (дата звернення: 08.11.2020)

6. Прунцева Г.О. Економічна сутність поняття «продовольча безпе-ка» країни. Інноваційна економіка. 2016. № 1-2. С. 34-37.

7. Пушак Я.Я., Пушак I.І. Самозабезпеченість продовольством регіону: оцінка та прогноз. Бізнес-навігатор, 2012. № 3 (29). С. 40-46.

8. Тринько Р.І. Соціально-економічна сутність та основні шляхи ре-алізації продовольчої безпеки в Україні. Науковий вісник ЛДУВС. 2006. № 2. С. 246-260.

9. FAO: its origins, formation and evolution, 1945-1981. Rome.: Food and Agriculture Organization of the United Nations, 1981. P. 11. URL: http://www.fao.org/docrep/009/p4228e/P4228E04.htm (дата звернення: 08.11.2020).

10. Food and nutrition security in the post 2015 framework. Beyond 2015. Thematic Position Paper. The Food and Agriculture Organization (FAO): веб-сайт. URL: http://www.fao.org/fsnforum/post2015/sites/post2015/files/resources/ Beyond2015 FNSPositionPaper_FINAL_0.pdf (дата звернення: 08.11.2020).

11. Masters L. The global food crisis and the challenge of food security. Lesley Masters. Pretoria : Africa Institute of South Africa. 2008. 408 p.

12. Quisumbing A.R., Brown L.R. et al. Women: The key to food securi-ty. IFPRI Food Policy. Washington, 1995. P. 12. URL: https://www.ifpri.org/publication/womenkey-food-security (дата звернення: 08.11.2020).

\section{References:}

1. Babenko A.A. (2005) Zabezpechennia prodovolchoi bezpeky Ukrainy $v$ umovakh reformuvanni $i$ rehuliuvannia ahrarnoho sektoru ekonomiky [Ensuring food security of Ukraine in terms of reforming and regulating the agri-cultural sector of the economy] (PhD Thesis). Luhansk: Luhanskyi natsionalnyi ahrarnyi universytet

2. Brodel' Fernan (2006) Material'naya tsivilizatsiya, ekonomika i kapitalizm, KhV-KhVIII vv. [Material civilization, economics and capitalism, XV-XVIII centuries]. Available at: http://demoscope.ru/weekly/knigi/brodel/brodel.pdf (accessed 08 November 2020).

3. The Economist Intelligence Unit (2020) Hlobalnyi indeks prodovolchoi bezpeky 2019 [Global Food Security Index 2019]. Available at: https://infoindustria.com.ua/opublikovano-globalnij-indeks-2019/ (accessed 08 November 2020).

4. Kashenko O.L. (2001) Ekolohichna skladova natsionalnoi prodovolchoi bezpeky. Nova ekonomichna paradyhma formuvannia stratehii natsionalnoi prodovolchoi bezpeky Ukrainy u KhKhI stolitti [Ecological component of national food security. A new economic paradigm of forming the strategy of national food security of Ukraine in the XXI century]. Kyiv: IAE. (in Ukrainian)

5. Verkhovna Rada Ukrainy (2011) Pro prodovolchu bezpeku Ukrainy [On food security of Ukraine]. Available at: http://search.ligazakon.ua/1_doc2.nsf/link1/JF6GI01I.html (accessed 08 November 2020).

6. Pruntseva H.O. (2016) Ekonomichna sutnist poniattia «prodovolcha bezpeka» krainy [The economic essence of the concept of "food security" of the country]. Innovatsiina ekonomika, no. 1-2, pp. 34-37.

7. Pushak Ya.Ya, Pushak I.I. (2012) Samozabezpechenist prodovolstvom rehionu: otsinka ta prohnoz [Food self-sufficiency of the region: assessment and forecast]. Biznes-navihator, no. 3 (29), pp. 40-46.

8. Trynko R.I. (2006) Sotsialno-ekonomichna sutnist ta osnovni shliakhy realizatsii prodovolchoi bezpeky v Ukraini [Socio-economic essence and main ways of food security in Ukraine]. Naukovyi visnyk LDUVS, no. 2, pp. $246-260$. 
9. FAO: its origins, formation and evolution, 1945-1981. Rome.: Food and Agriculture Organization of the United Nations, 1981. P. 11. Available at: http://www.fao.org/docrep/009/p4228e/P4228E04.htm (accessed 08 November 2020).

10. Food and nutrition security in the post 2015 framework. Beyond 2015. Thematic Position Paper. The Food and Agriculture Organization (FAO). Available at: http://www.fao.org/fsnforum/post2015/sites/post2015/files/resources/ Beyond2015_FNSPositionPaper_FINAL_0.pdf (accessed 08 November 2020).

11. Masters L. The global food crisis and the challenge of food security. Lesley Masters. Pretoria: Africa Institute of South Africa. 2008. 408 p.

12. Quisumbing A.R., Brown L.R. et al. Women: The key to food security. IFPRI Food Policy. Washington, 1995. P. 12. Available at: https://www.ifpri.org/publication/womenkey-food-security (accessed 08 November 2020).

\section{ТЕОРЕТИЧЕСКИЕ ОСНОВЫ ОБЕСПЕЧЕНИЯ ПРОДОВОЛЬСТВЕННОЙ БЕЗОПАСНОСТИ}

Проблема обеспечения продовольственной безопасности была и остается актуальной для человечества, ведь непосредственно связана с необходимостью систематического удовлетворения первоочередной физиологической потребности в пище. Рост количества населения, несмотря на существенный прогресс в более эффективном использовании природных ресурсов, актуализирует важность научного поиска путей достижения физической и экономической достаточности продуктов питания. Последние десятилетия ознаменовались определенным изменением спектра приоритетных задач, когда рядом с количеством еды важными стали ее качественные параметры, то есть содержание необходимых для поддержания жизнеспособности минералов, отсутствие вредных составляющих и систематичность поступления продуктов независимо от урожайности и интенсивности внутри- и внешнеэкономических процессов в стране.

Ключевые слова: продовольственная безопасность, безопасность питания, продукть питания, продовольственная доступность, продовольственная достаточность.

\section{THEORETICAL FUNDAMENTALS OF SECURITY FOOD SECURITY}

The problem of food security has been and remains relevant for mankind, because it is directly related to the need to systematically meet the primary physiological need for food. Population growth, with significant progress in more efficient use of natural resources, highlights the importance of scientific search for ways to achieve physical and economic sufficiency of food. The last decades have been marked by a change in the range of priorities, when along with the amount of food, its quality parameters became important, ie the capacity needed to maintain the viability of minerals, the absence of harmful components and regular supply of products regardless of yield and intensity of domestic and foreign economic processes. The research is focused on determining the stages of formation of the concept of "food security", highlighting the main scientific approaches to its interpretation and outlining aspects of security in the modern conditions of development of our country. To form the theoretical foundations of food security, the following methods were used: induction and deduction, comparison and systematization - in the study of the essential characteristics of the terms "food security" and "food security"; synthesis and analysis - for the formation of theoretical provisions for food security; morphological analysis - to characterize the changing priorities of food security; abstract logical-for theoretical generalizations and conclusions of the study. Four main approaches to the interpretation of the essence of the term "food security" are identified and characterized, each of which reflects an important aspect that deserves attention. The generalization made it possible to prove the priority of food security for each state as a basis for preserving its independence. For our country, the problem of food security is associated with hostilities, low purchasing power, technological backwardness of agricultural enterprises, irrational use of land resources, growing imported food and the impact of other internal and external factors. It is proved that scientific substantiation is required by: ways to achieve a sufficient number of food products, ensuring the availability of food for all segments of the population; mechanisms for controlling the composition and quality of products, as well as the stability of their supply.

Key words: food security, food security, food, food availability, food adequacy. 